\title{
PENGARUH REKRUITMEN, PELATIHAN DAN PENGEMBANGAN TERHADAP KINERJA KARYAWAN PT BANK DANAMON INDONESIA TBK
}

\author{
Iir Abdul Haris ${ }^{1}$, Rival Achmadi ${ }^{2}$, Rizma Kartika ${ }^{3}$, Sarah Fadilah Zein ${ }^{4}$, Silvi \\ Rahmadini $^{5}$, Siti Hanita ${ }^{6}$, Zahra Zaharani Yusuf ${ }^{7}$ \\ 1,2,3,4,5,6,7 UIN Sunan Gunung Djati Bandung \\ Email : abdul.haris@uinsgd.ac.id
}

\begin{abstract}
Abstrak
Dalam era globalisasi ini sumber daya manusia yang bermutu sangatlah diperlukan karena tolak ukur maju mundurnya suatu perusahaan sangat tergantung pada kualitas sumber daya manusia nya. Sumber daya ini menunjang organisasi dengan karya, bakat, kreativitas, sehingga kenyataan membuktikan, bahwa seorang karyawan merupakan aset pokok tujuan perusahaan tercapai. Sumber daya yang berkualitas ditentukan oleh sistem rekruitmen dan pelatihan yang baik. Penelitian ini bertujuan untuk mengetahui pengaruh rekrutmen dan pelatihan terhadap kinerja karyawan PT. Bank Danamon Indonesia, Tbk. Adapun metode analisis data dalam penelitian ini menggunakan pendekatan deskriptif kualitatif dengan teknik pengumpulan data yang diperoleh dari laporan tahunan perusahaan yang sudah di publikasikan di website PT. Bank Danamon Indonesia Tbk. Hasil penelitian ini menunjukkan bahwa rekrutmen dan pelatihan berpengaruh secara signifikan terhadap kinerja karyawan. Faktor rekrutmen dan pelatihan sangat mempengaruhi kinerja karyawan sehingga faktor rekrutmen dan pelatihan harus di perhatikan.
\end{abstract}

Kata kunci: Rekrutmen, Pelatihan, Pengembangan, dan Kinerja.

\begin{abstract}
In this era of globalization, qualified human resources are very necessary because the benchmark of the progress of a company depends on the quality of its human resources. These resources support the organization with wok, talent, creativity, so that the reality proves that an employee is the achieved. Quality resources are determined by a good recruitment and training system. This study aims to determine the effect of recruitmen and training on the performance of employees of PT. Bank Danamon Indonesia Tbk. The analysis method in this study uses a descriptuve qualitative approach with data collection techniques obtained from the company's annual report that has been published on the website of PT. Bank Danamon Indonesia Tbk. The results of this study indicate that recruitment and training significantly influence employee performance. Recruitment and training factors greatly affect employee performance so recruitment and training factors must be considered.
\end{abstract}

Keywords: Recruitment, Training, Development and Performance 


\section{A. PENDAHULUAN}

Sumber daya manusia merupakan aspek penting dalam suatu organisasi atau perusahaan. Pengelolaan Sumber Daya Manusia (SDM) merupakan hal yang penting dalam pencapaian tujuan. Keberhasilan suatu perusahaan sangat bergantung kepada kualitas kinerja karyawannya. Kinerja yang baik akan berdampak langsung pada kemajuan atau kemunduran perusahaan. Terdapat banyak factor yang dapat mempengaruhi kualitas kinerja perusahaan diantaranya rekruitmen, pelatihan, pengembangan, budaya organisasi, karakter pemimpin perusahaan, dll. Menurut (Hasibuan, 2002:160) kinerja adalah hasil kerja yang dicapai seseorang dalam melaksanakan tugas tugasnya atas kecakapan, usaha dan kesempatan. Kinerja juga merupakan suatu hasil yang dicapai seseorang dalam melaksanakan tugas-tugas yang didasarkan atas kecakapan, pengalaman dan kesungguhan serta waktu menurut standard an kriteria yang telah ditetapkan.

Dalam upaya meningkatkan kinerja karyawan PT Bank Danamon Indonesia, Tbk melakukan rekruitmen dalam memilih karyawan yang unggul serta menyelenggarakan program pelatihan dan pengembangan untuk menciptakan karyawan yang berkualitas. Rekrutmen, seleksi, training and development calon tenaga kerja merupakan salah satu kunci dalam menciptakan sumber daya manusia (SDM) yang professional. Mencari tenaga kerja yang berkualitas dan professional tidaklah mudah. Adalah sebuah kewajiban bagi organisasi/perusahaan untuk melakukan penyaringan anggota atau pekerja yang baru.

Menurut Henry Simamora (1997:212), Rekrutmen adalah serangkaian aktivitas mencari dan memikat pelamar kerja dengan motivasi, kemampuan, keahlian, dan pengetahuan yang diperlukan guna menutupi kekurangan yang diidentifikasi dalam perencanaan kepegawaian. Pada hakikatnya tujuan dari rekrutmen adalah untuk memenuhi kebutuhan perusahaan dalam hal sumber daya manusia (SDM). Rekrutmen dengan segala prosesnya diharapkan memungkinkan perusahaan dapat memenuhi harapan untuk mendapatkan untuk mendapat SDM yang berkualitas dan professional sesuai dengan kriteria mereka. 
Selain dari rekrutmen, hasil kinerja dari SDM juga sangat erat hubungannya dengan pelatihan dan pengembangan SDM pada sebuah perusahaan. Oleh sebab itu, diperlukan adannya suatu penilaian untuk mengukur kinerja dan pelatihan SDM yang dilakukan setelah mendapat hasil dari penilaian tersebut. Tujuan dari pelatihan karyawan itu sendiri adalah supaya para karyawan memiliki pengetahuan, kemampuan dan keterampilan sesuai dengan apa yang menjadi tuntutan pekerjaan yang mereka lakukan.

Karyawan atau sumber daya manusia (SDM) yang duduk di suatu jabatan dalam sebuah perusahaan terkadang meiliki level atau taraf kemampuan yang berbeda dengan karyawan lainnya. Terkadang kemampuan mereka kemampuan mereka naik/meningkaat, dan terkadang juga cenderung menurun. Dan ada juga yang memiliki kemampuan kurang sesuai dengan apa yang dibutuhkan dalam jabatan tersebut. Hal tersebut bisa terjadi disebabkan seseorang menduduki jabatan tertentu karena bukan kemmampuannya. Bisa saja karyawan itu mendapatkan jabatannya karena kedekatannya dengan manajer atau karena terlalu terburu-burunya pihak HR dalam merekrut karyawan. Oleh sebab itu, karyawan baru tersebut perlu menambah keahlian dan kemampuannya. Itu merupakan arti penting dari pelatihan karyawan.

Karyawan dapat lebih berkemampuan memahami dan dan mengembangkan seluk-beluk pekerjaan secara lebih mendalam, dapat memahami perkembangan pada perusahaan, memahami sasaran yang telah ditetapkan perusahaan, mengerti akan pentingnya kerjasama dalam melakukan pekerjaan, dapat dengan mudah menyerap informasi yang disampaikan perusahaan, dan berkemampuan memamahami serta menerapkan perilaku yang dituntut perusahaan.

Manfaat pelatihan karyawan bagi perusahaan:

a. Perusahaan dapat beradaptasi dengan dengan keadaan lingkungan sekarang.

b. Perusahaan memiliki SDM yang dapat mel;aksanakan pekerjaan dengan baik.

c. Tantangan perkembangan zaman dapat dijawab oleh perusahaan.

d. Meningkatnya prestasi dan produktivitas perusahaan.

e. Persiapan para karyawan untuk menduduki posisi yang lebih tinggi pada perusahaan. 
Pelatihan dan pengembangan karyawan di suatu perusahaan merupakan suatu keharusan untuk memaksimalkan SDM di perusahaan tersebut. HR sangat berperan penting bagi berkembangnya perusahaan.

\section{B. KAJIAN PUSTAKA}

\section{Rekruitmen}

Hasibuan (2011) menjelaskan bahwa penarikan (rekruitmen) adalah usaha mencari dan mempengaruhi tenaga kerja agar mau melamar lowongan pekerjaan yang ada dalam suatu perusahaan. Rekruitmen merupakan suatu cara untuk memperoleh orang yang tepat untuk menduduki suatu jabatan tertentu dalam perusahaan.

Singodimejo (2000) rekruitmen merupakan suatu proses mencari, mengadakan, menemukan dan menarik para pelamar untuk dipekerjakan dalam dan oleh suatu organisasi.

Gomes (1995) rekruitmen merupakan proses mencari, menemukan dan menarik para pelamar untuk dipekerjakan dalam dan oleh suatu organisasi.

Sculer dan Jackson (1997) dalam (Nuryanta, 2008) rekruitmen antara lain meliputi upaya pencarian sejumlah calon karyawan yang memenuhi syarat dalam jumlah tertentu sehingga dari mereka organisasi dapat menyeleksi orang-orang yang paling tepat untuk mengisi lowongan pekerjaan yang ada.

\section{Pelatihan}

Menurut Widodo (2015:82), pelatihan merupakan serangkaian aktivitas individu dalam meningkatkan keahlian dan pengetahuan secara sistematis sehingga mampu memiliki kinerja yang professional di bidangnya. Pelatihan adalah proses pembelajaran yang memungkinkan pegawi melaksanakan pekerjaan yang sekarang sesuai dengan standar.

Menurut Rachmawati (2008:110), pelatihan merupakan wadah lingkungan bagi karyawan, dimana mereka memperoleh atau mempelajari sikap, kemampuan, keahlian, pengetahuan dan perilaku spesifik yang berkaitan dengan pekerjaan. 
Menurut Rivai dan Sagala (2011:212), pelatihan adalah proses secara sistematis mengubah tingkah laku pegawai untuk mencapai tujuan organisasi. Pelatihan berkaitan dengan keahlian dan kemampuan pegawai untuk melaksanakan pekerjaan saat ini.

\section{Pengembangan}

Menurut Tessmer dan Richey (Alim Sumarno, 2012) pengembangan memusatkan perhatiannya tidak hanya pada analisis kebutuhan, tetapi juga isu-isu luas tentang analisis awal-akhir, seperti analisis kontekstual. Pengembangan bertujuan untuk menghasilkan produk berdasarkan temuan-temuan uji lapangan.

Menurut Iskandar Wiryokusumo (Ali, 2013: 05) pada hakikatnya pengembangan merupakan upaya pendidikan baik formal maupun non formal yang dilaksanakan secara sadar, berencana, terarah, teratur dan bertanggung jawan dalam rangka memperkenalkan, menumbuhkan, membimbing, mengembangkan suatu dasar kepribadian yang seimbang, utuh, selaras, pengetahuan, keterampilan sesuai dengan bakat, keinginan serta kemampuan-kemampuan, sebagai bekal atas prakarsa sendiri untuk menambah, meningkatkan, mengembangkan diri kearah tercapainya martabat, mutu dan kemampuan manusiawi yang optimal serta pribadi mandiri.

\section{Kinerja Karyawan}

Menurut Yuwalliatin (dalam mangkunegara, 2006: 67) mengatakan bahwa kinerja diukur dengan instrument yang dikembangkan dalam studi yang bergabung dalam ukuran kinerja secara umum kemudian diterjemahkan kedalam penilaian perilaku secara mendasar, meliputi :

1. Kuantitas kerja

2. Kualitas kerja

3. Pengetahuan tentang pekerjaan

4. Perencanaan kegiatan

Pengertian kinerja karyawan menurut Hasibuan (2007:105) adalah suatu hasil kerja yang dicapai seseorang dalam melaksanakan tugas-tugas yang dibebankan kepadanya didasarkan atas kecakapan, pengalaman, dan kesungguhan serta waktu. 
Menurut Mangkunegara (2006:67) kinerja adalah hasil kerja secara kualitas dan kuantitas yang dicapai oleh seorang pegawai dalam melaksanakan tugasnya sesuai dengan tanggung jawan yang diberikan kepadanya.

Menurut Mathis (2002:78) kinerja karyawan adalah apa yang dilakukakn oleh seorang karyawan yang mempengaruhi seberapa banyak mereka memberi kontribusi kepada organisasi yaitu dalam arti kualitas, kuantitas output, jangka waktu output, kehadiran di tempat kerja, dan sikap kooperatif.

\section{METODE PENELITIAN}

Metode yang digunakan dalam penelitian ini adalah pendekatan deskriptifkualitatif karena peneliti ingin menggambarkan atau melukiskan fakta-fakta atau keadaan yang nampak dalam sistem perekrutan serta pelatihan dan pengembangan di PT Bank Danamon Indonesia, Tbk. Deskriptif-kualitatif labih menekankan pada aspek pemahaman secara mendalam terhadap suatu masalah. Teknik pengumpulan data yang digunakan dalam penelitian adalah kajian pustaka sebagai instrumennya peneliti sendiri mencari sumber penelitian dari berbagai referensi.

\section{Jenis dan Sumber Data:}

Sumber data yang digunakan dalam penelitian ini adalah :

1. Data primer

Data yang secara langsung diperoleh dari objek penelitian dan masih harus diteliti serta memerlukan pengolahan lebih lanjut lagi. Data-data tersebut seperti hasil pengamatan seperti rata-rata jumlah yang dilakukan, jumlah peserta, instruktur, dll.

2. Data sekunder

Data yang diperoleh dari institusi/perusahaan dan data tersebut sudah diolah seperti gambaran umum perusahaan, struktur organisasi, standar waktu, dsb. Data ini juga dapat diperoleh dari mempelajari pustaka dan literature lainnya yang memiliki relevansi dengan sasaran penelitian.

\section{Teknik Pengumpulan Data}


Teknik data yang diperoleh dalam penyusunan penelitian ini yaitu menggunakan teknik penelitian lapangan (Field Research), dalam mengumpulkan data lapangan penulis menganalisis secara langsung pada objek yang sedang diteliti dengan maksud untuk mendapatkan data primer tentang sesuatu yang berhubungan dengan masalah pelaksanaan antrian dimana pengumpulan data dilakukan dengan cara :

1. Wawancara (Interview)

Teknik pengumpulan data dengan cara mengadakan tanya jawab dengan bagian yang terkait dengan penelitian

2. Observasi (Observation)

Teknik pengumpulan data dengan mengamati objek penelitian yang bersangkutan secara langsung. Hasil observasi dapat dijadikan sebagai data pendukung dalam menganalisis dan mengambil keputusan.

3. Tinjauan Pustaka (Library Research)

Bentuk pengumpulan data yang dilakukan dengan mempelajari berbagai literature, karya ilmiah, serta penelitian sebelumnya yang berkaitan dan mendukung data dalam penulisan penelitian ini.

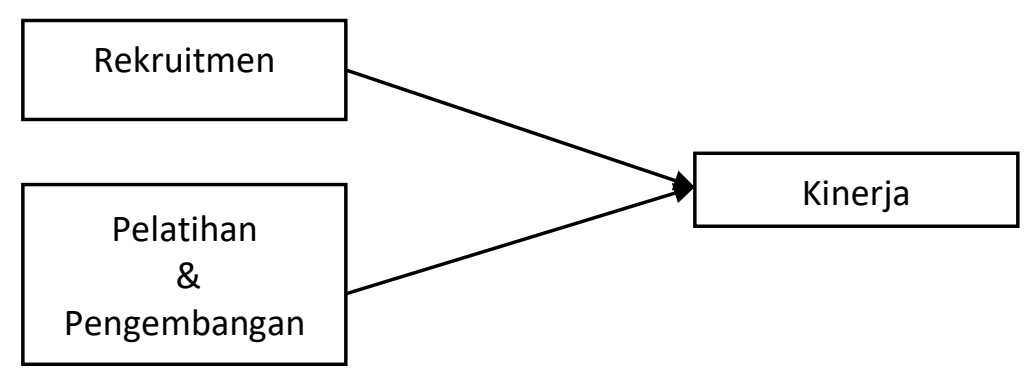

\section{HASIL DAN PEMBAHASAN}

\section{Pelatihan dan Pengembangan}

PT Bank Danamon Indonesia Tbk yang berdiri sejak 1956, per 31 Desember 2019 mengelola aset sebesar Rp194 triliun bersama anak perusahaannya, yaitu PT Adira Dinamika Multi Finance Tbk. (Adira Finance). Dalam hal kepemilikan saham, 94,1\% saham Bank Danamon dimiliki oleh MUFG Bank, Ltd. dan 5,9\% dimiliki oleh publik.

Bank Danamon didukung oleh 960 jaringan kantor cabang konvensional, unit Syariah dan kantor cabang anak perusahaannya serta lebih dari 60.000 jaringan ATM 
Danamon, ATM Bersama, PRIMA dan ALTO yang tersebar di 34 provinsi. Selain jaringan fisik, layanan Danamon juga dapat diakses melalui Danamon Online Banking, aplikasi D-Bank, D-Card, serta SMS Banking.

Menjadi bagian dari MUFG Bank sebagai bank terbesar di Jepang dan salah satu institusi keuangan termuka di dunia akan memberikan nilai tambah. Bank Danamon akan dapat mengakses kekuatan, keahlian dan jaringan MUFG untuk melayani nasabah kami dan memfasilitasi pertumbuhan Bank Danamon dalam mewujudkan nilai jangka panjang bagi seluruh pemangku kepentingan.

Bank Danamon menerima penghargaan dari Infobank Banking Service Excellence Awards 2019 untuk Pelayanan Menyeluruh, termasuk Peringkat Satu Layanan Teller \& SMS Banking serta Peringkat Dua Pembukaan Rekening via Aplikasi Mobile. Sebelumnya Bank Danamon juga menjadi Best Digital Bank Indonesia pada ajang Asiamoney Best Bank Award 2018 di Beijing. Bank Danamon also juga menerima penghargaan The Asian Banker Indonesia Award 2019 dalam kategori Best Digital KYC and Account Opening Initiative, Application, or Programme dari The Asian Banker.

Tidak hanya fokus pada kemitraan institusi, pengembangan SDM juga menjadi prioritas Bank Danamon. Salah satu best practice yang ingin diterapkan MUFG di Bank Danamon adalah memberikan kesempatan bagi karyawan melakukan internal movement atau peluang bekerja di unit kerja lain di dalam MUFG Group. Hal ini memungkinkan karyawan untuk bekerja di cabang MUFG Bank yang tersebar di beberapa negara.

Melalui kemitraan yang kuat tersebut, karyawan juga mendapat kesempatan mengikuti program magang intensif selama tiga bulan di kantor pusat MUFG Bank di Tokyo, atau di sejumlah mitra perbankan lain MUFG seperti Krungsri Bank di Thailand, Security Bank di Phillippines serta Vietin Bank di Vietnam. Karyawan Danamon memiliki akses kepada program pelatihan MUFG Group di dalam maupun luar negeri.

Dengan kehadiran MUFG, karyawan Bank Danamon memiliki akses ke Digital Innovation Center milik MUFG Bank yang berada di Silicon Valley, California, New 
York, London, dan Singapura yang dapat memperkuat kemampuan digital karyawan yang tentunya akan membantu dalam melayani kebutuhan nasabah. Selain mengikuti perkembangan zaman, juga untuk memenuhi kebutuhan nasabah yang saat ini haus teknologi dan tidak ingin disibukkan dengan aktivitas mengantri ataupun lainnya.

Sehingga, terangnya dengan kemudahan yang diberikan Bank Danamon akan memberikan kenyamanan, keamanan, dan yang utama adalah praktis bagi nasabah khususnya nasabah milenial. Selain itu, lanjutnya, dengan transformasi layanan digital perbankan memberikan dampak positif dalam menekan biaya operasional.

Kegiatan Training Center di gelar di Danamon Corporate University lebih mengedepankan konsep kenyamanan dan ketenangan. Keberadaan Danamon Corporate University, pusat pelatihan karyawan yang terletak di Ciawi, Jawa Barat juga merupakan salah satu wujud nyata keseriusan Bank Danamon dalam pengembangan karyawan. Di dalam kompleks bangunan ala kampus ini terdapat fasilitas mumpuni seperti ruang kelas, arena olahraga serta asrama dan juga area ballroom masif.

Keberadaan pusat pelatihan cukup penting, di mana corporate university berperan tidak cuma sekadar pemberian pelatihan, tapi juga dapat menjadi assestment center dan think thank perusahaan. Bank Danamon juga sudah menerapkan digital learning kepada karyawannya, sehingga memudahkan proses belajar karena dapat dilakukan di mana saja dan kapan saja. Selain itu, ada juga program D-talk di mana perusahaan kerap mengundang pakar-pakar dari berbagai industri sebagai pembicara untuk berbagi ilmu dan pengalaman dalam acara seminar atau workshop.

Guna melahirkan SDM unggul khususnya dalam industri perbankan, Bank Danamon rutin melaksanakan program DBT (Danamon Bankers Trainee), sebuah program Management Trainee yang terbuka bagi mereka yang baru lulus kuliah di mana peserta mendapat pembelajaran terstruktur yang akan memberi pengalaman menyeluruh tentang proses, peraturan, manajemen risiko, produk, dan layanan bisnis perbankan yang mencakup area back, middle dan front office.

Peserta DBT akan melewati dua fase pelatihan. Pertama, fase pembelajaran inclass selama lima bulan, dilanjutkan fase project assignmentyang berjalan selama tujuh bulan. Dua tahun terakhir, program DBT digelar dua kali setahun dengan partisipan 
mencapai 50 orang. Tahun ini, Bank Danamon akan melaksanakan program DBT sebanyak empat kali dalam setahun dan melibatkan lebih banyak partisipan, sekitar 200 peserta.

Bertujuan untuk melebihi harapan nasabah, Danamon senantiasa mengembangkan karyawan kami melalui berbagai program pembelajaran, pelatihan dan pengembangan. Bank memberikan berbagai program pelatihan dan materi yang dikembangkan untuk memastikan setiap karyawan mampu meningkatkan kinerjanya, mengembangkan karir mereka, dan berkontribusi dalam pertumbuhan bisnis perusahaan.

Danamon memiliki fasilitas Danamon Corporate University (DCU) yang memfasilitasi karyawan dengan pengetahuan dan ketrampilan sehingga mereka dapat mencapai target kinerja ataupun target personal. Pusat pelatihan yang berlokasi di Ciawi, Jawa Barat, dilengkapi dengan enam program perkuliahan, yaitu: Retail \& SME Banking, Keuangan Mikro, Wholesale Banking, Manajemen Risiko, Operasional \& Teknologi dan Pusat Inovasi. Pada tahun 2014, Danamon telah menggelar sebanyak 2.948 program pelatihan yang diikuti oleh 70.278 peserta dari Danamon dan juga anak perusahaan di seluruh Indonesia.

Selain itu, Danamon telah mengembangkan pelatihan dan bimbingan onthe-job training yang pelaksanaannya dibantu oleh karyawan yang lebih berpengalaman atau supervisor sebagai mentor terhadap bawahan mereka. Topik pelatihan dan pelajaran yang mencakup kemampuan manajerial, keterampilan teknis, kursus penyegaran, kursus hak asasi manusia, dan lain sebagainya.

\section{Rekruitmen}

Bank Danamon merekrut karyawan melalui website resminya dan juga bekerja sama dengan beberapa website untuk merekrut karyawan baru diantaranya jobstreet.co.id, bursakerjadepnaker.com, openkerja.id, indeed.com, dan masih banyak lagi. Salah satu program yang dimiliki Bank Danamon yaitu Danamon Bankers Trainee (DBT). Danamon Bankers Trainee (DBT) merupakan program Management Trainee Bank Danamon dimana para lulusan baru berbakat diberikan kesempatan untuk mencari pengalaman di berbagai bisnis, divisi dan fungsi di dalam Bank. 
Danamon Bankers Trainee merupakan sejenis Management Trainee ataupun Officer Development Program yang baru ada sejak tahun 2017. Program ini meliputi pendidikan dan on the job training selama dua tahun dan memiliki sistem cut untuk setiap periodenya jika peserta didik dinilai tidak memenuhi kualifikasi standar dari perusahaan. Peserta nantinya akan diberikan sertifikasi khusus dan ketika lulus nantinya berhak menyandang gelar OMEGA dibelakang namanya. Seleksi bersifat terbuka, professional dan sangat jelas terkait dalam artian tahapan seleksi jelas, informasi terkait seleksi juga tetap diberitahukan kepada peserta, lolos maupun tidak lolos tetap diinformasikan oleh $H R$ juga dalam komunikasinya sangat mudah.

Adapun keunggulan dari program ini diantaranya :

1. Menjadi program pembelajaran terstruktur yang akan memberi pengalaman menyeluruh tentang proses, peraturan, manajemen risiko, produk dan layanan bisnis perbankan yang mencakup area back, middle \& front office

2. Pengembangan kemampuan berpikir \& bekerja secara strategis, kreatifitas, dan ketajaman bisnis

3. Pengembangan kepemimpinan

4. Akses untuk bertemu dan berinteraksi langsung dengan para Top Executives dan Senior Leaders

5. Pairing dengan Mentor \& Buddy selama program untuk pengembangan karir professional

Selain itu, untuk dapat lolos pada program ini peserta harus memenuhi persyaratan kualifikasi dan beberapa seleksi. Kualifikasi tersebut diantaranya:

1. Memiliki motivasi tinggi, berorientasi pada hasil, gigih, dan tangguh

2. Memiliki kemampuan analisa, komunikasi, dan interpersonal yang baik

3. Memiliki kemampuan berbahasa inggris yang baik, lisan maupun tulisan. Skor TOEFL/IELTS/TOEIC minimum 500/6/550

4. Lulusan $\mathrm{S} 1$ atau $\mathrm{S} 2$ dari universitas ternama, baik dalam maupun luar negeri

5. IPK minmal 3,25 dari skala 4,00

6. Usia maksimal lulusan bari S1 (23 Tahun) dan S2 (25 Tahun)

7. Usia maksimal dengan pengalaman kerja maksimal 2 Tahun S1 (25 Tahun) dan S2 (27 Tahun) 
Adapun tahapan seleksi Danamon Bankers Trainee (DBT), diantaranya :

1. Pendaftaran Online

Pada tahap ini, calon peserta mendaftar pada website resmi Bank Danamon dan mengisi formulir beserta persyaratan yang harus dilampirkan

2. Online Assessment

Tahap selanjutnya adalan online Assessment (psikotes). Untuk psikotes sendiri dilaksanakan oleh Talentlytica, sebuah HR Platform yang membantu Bank Danamon untuk mengadakan psikotes online.

3. Focus Group Discussion dan Wawancara HRD

Pada tahap ini diawali dengan mengisi biodata berupa data pribadi lengkap, riwayat pendidikan, prestasi, kursus, keluarga, dll. Setelah itu terdapat penjelasan yang dilakukan oleh petinggi Bank Danamon mengenai Bank Danamon dan program Danamon Bankers Trainee (DBT). Dalam focus group discussion, peserta dibagi menjadi beberapa kelompok yang mana satu kelompok terdiri dari 5-6 orang peserta. Pada tahap FGD, peserta diminta untuk mencari solusi dari sebuah kasus, setelah itu peserta diberikan waktu untuk memahami kasus dan merancang argument. Pada tahap ini, peserta yang lolos hanya $25 \%$. Peserta yang lolos selanjutnya melalui tahap wawancara HRD. 50\% peserta yang lolos dalam tahap wawancara HRD.

4. In Tray

Pada tahap ini, peserta diuji dengan diberikan sebuah kasus dan diminta untuk menyelesaikan kasus tersebut. Kasus yang diberikan adalah kasus seputar perbankan. Peserta diminta untuk menulis dan mempresentasikan solusi dari kasus tersebut kepada petinggi bank.

5. Wawancara User (Wawancara Tahap 2)

Tahap ini adalah tahap seleksi terakhir. Wawancara dilakukan oleh BOD Bank Danamon. 


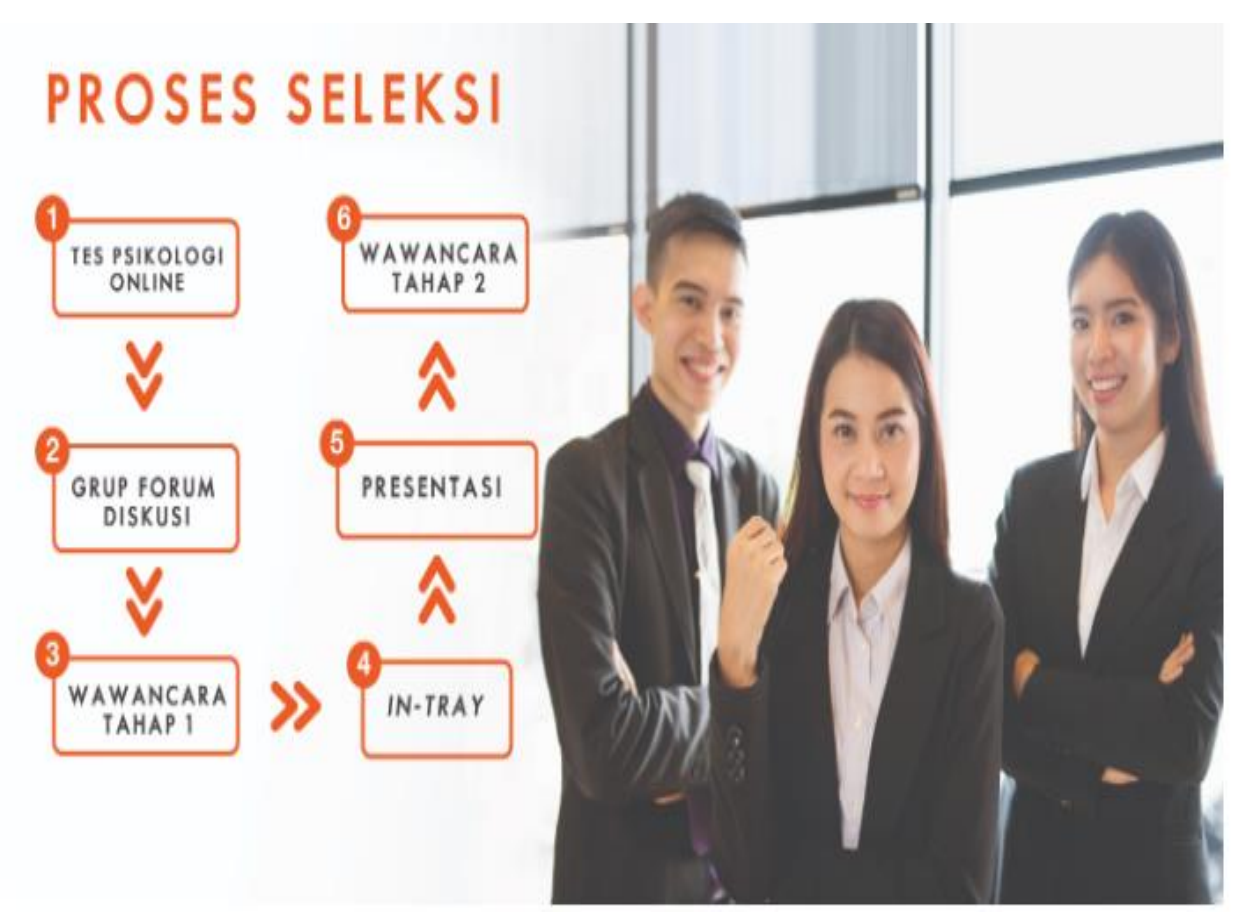

Gambar 1 Proses seleksi Bank Danamon

Sumber : Danamon Bankers Trainee

Tabel 1

Jumlah Karyawan Bank Danamon 2019

Data Headcount per Desember 2019 (Konsolidasi) PT Danamon Indonesia, Tbk

\begin{tabular}{|lccc|}
\hline \multicolumn{1}{|c}{ Perusahaan } & $\mathbf{2 0 1 9}$ & $\mathbf{2 0 1 8}$ & $\mathbf{2 0 1 7}$ \\
\hline Danamon & 10.382 & 12.442 & 16.811 \\
\hline Adira Finance & 17.667 & 19.028 & 18.760 \\
& & & 839 \\
\hline Adira Insurance & - & 759 & $\mathbf{3 6 . 4 1 0}$ \\
\hline Total & $\mathbf{2 8 . 0 5 9}$ & $\mathbf{3 2 . 2 9 9}$ & \\
\hline
\end{tabular}

* Sejak November 2019 Adira Insurance tidak termasuk dalam laporan konsolidasi Danamon

Sumber : Annual Report Bank Danamon 2019 
Tabel 2

Jumlah Karyawan Bank Danamon 2019

Komposisi Karyawan Berdasarkan Level Organisasi (Kondolidasian)

\begin{tabular}{|lccc|}
\hline Tingkat Jabatan & $\mathbf{2 0 1 9}$ & $\mathbf{2 0 1 8}$ & $\mathbf{2 0 1 7}$ \\
\hline $\begin{array}{l}\text { Manajemen Puncak } \\
\text { dan Technical } \\
\text { Advisor }\end{array}$ & 22 & 26 & 24 \\
\hline Manajer Senior & 339 & 329 & 340 \\
\hline Manajer & 2.934 & 3.192 & 3.376 \\
\hline Officer & 8.380 & 9.640 & 11.369 \\
\hline Staf & 16.384 & 19.112 & 21.301 \\
\hline Total & $\mathbf{2 8 . 0 5 9}$ & $\mathbf{3 2 . 2 9 9}$ & $\mathbf{3 6 . 4 1 0}$ \\
\hline
\end{tabular}

Sumber : Annual Report Bank Danamon 2019

Tabel 3

Jumlah Karyawan Bank Danamon 2019

Komposisi Karyawan Berdasarkan Lama Bekerja (Konsolidasi)

\begin{tabular}{|cccc|}
\hline Lama Kerja & $\mathbf{2 0 1 9}$ & $\mathbf{2 0 1 8}$ & $\mathbf{2 0 1 7}$ \\
\hline 0-3 Tahun & 8.975 & 10.975 & 11.213 \\
\hline 3-5 Tahun & 3.138 & 3.230 & 3.757 \\
\hline 5-10 Tahun & 7.946 & 10.179 & 12.998 \\
\hline 10-20Tahun & 5.894 & 5.554 & 5.883 \\
\hline > 20 Tahun & 2.106 & 2.361 & 2.649 \\
\hline Total & $\mathbf{2 8 . 0 5 9}$ & $\mathbf{3 2 . 2 9 9}$ & $\mathbf{3 6 . 4 1 0}$ \\
\hline
\end{tabular}

Sumber : Annual Report Bank Danamon 2019

Tabel 4

Jumlah Karyawan Bank Danamon 2019

Komposisi Karyawan Berdasarkan Usia (Konsolidasi)

\begin{tabular}{|cccc|}
\hline Umur & $\mathbf{2 0 1 9}$ & $\mathbf{2 0 1 8}$ & $\mathbf{2 0 1 7}$ \\
\hline$<$ 25 Tahun & 1.763 & 3.218 & 2.603 \\
\hline 25-34 Tahun & 11.633 & 16.189 & 19.252 \\
\hline 35-44 Tahun & 11.173 & 9.533 & 11.340 \\
\hline$>$ 45 Tahun & 3.490 & 3.359 & 3.215 \\
\hline Total & $\mathbf{2 8 . 0 5 9}$ & $\mathbf{3 2 . 2 9 9}$ & $\mathbf{3 6 . 4 1 0}$ \\
\hline
\end{tabular}

Sumber : Annual Report Bank Danamon 2019 
ARTIKEL

Tabel 5

Jumlah Karyawan Bank Danamon 2019

Komposisi Karyawan Berdasarkan Pendidikan (Konsolidasi)

\begin{tabular}{|cccc|}
\hline Pendidikan & $\mathbf{2 0 1 9}$ & $\mathbf{2 0 1 8}$ & $\mathbf{2 0 1 7}$ \\
\hline Pasca Sarjana & 419 & 415 & 461 \\
\hline Sarjana & 19.620 & 22.159 & 24.733 \\
\hline Diploma & 5.204 & 6.037 & 6.932 \\
\hline SLTA & 2.812 & 3.680 & 4.272 \\
\hline SLTP/SD & 4 & 8 & 12 \\
\hline Total & $\mathbf{2 8 . 0 5 9}$ & $\mathbf{3 2 . 2 9 9}$ & $\mathbf{3 6 . 4 1 0}$ \\
\hline
\end{tabular}

Sumber : Annual Report Bank Danamon 2019

Tabel 6

Jumlah Karyawan Bank Danamon 2019

Komposisi Karyawan Berdasarkan Status Kepegawaian (Konsolidasi)

\begin{tabular}{|cccc|}
\hline Status Kepegawaian & $\mathbf{2 0 1 9}$ & $\mathbf{2 0 1 8}$ & $\mathbf{2 0 1 7}$ \\
\hline Permanen $^{1}$ & 22.999 & 26.389 & 29.596 \\
\hline Non Permanen $^{2}$ & 5.060 & 5.910 & 6.814 \\
\hline Total & $\mathbf{2 8 . 0 5 9}$ & $\mathbf{3 2 . 2 9 9}$ & $\mathbf{3 6 . 4 1 0}$ \\
\hline
\end{tabular}

Sumber : Annual Report Bank Danamon 2019

1) Karyawan Permanen meliputi permanen dan probation

2) Karyawan Non Permanen meliputi kontrak, trainee, honor dan ekspatriat. Data tidak termasuk dengan karayawan outsource

Pada tahun 2019 Bank Danamon telah merekrut sebanyak 2.378 orang yang terbagi dalam rekruitmen 43 orang di tingkat Senior Management, 146 orang di tingkat Middle Management, 935 orang di First Line Management dan 374 orang di tingkat Clerical.

Bank Danamon melakukan penggabungan dengan BNP, oleh karena itu Bank Danamon juga telah menerima 880 karyawan di bagian Business Banking. Selain karyawan permanen atau karyawan tetap, Bank Danamon merekrut 48 Danamon Bankers Trainee (DBT) yang telah mengikuti program pendidikan yang dimulai pada 
bulan April dan Oktober 2019. Dalam rekruitmen karyawan Bank Danamon melakukan beberapa inovasi, diantaranya :

- Bekerja sama dengan professional career site seperti Linkedin dan memanfaatkan media social Instagram untuk melakukan corporate branding serta job posting dengan tujuan menarik serta memperoleh kandidat yang sesuai untuk professional hire maupun fresh fraduates.

- Melanjutkan kerjasama dengan Universitas terkemuka dan organisasi alumni Universitas guna mendapatkan Bank data talenta-talenta fresh graduates untuk dapat diseleksi mengikuti Danamon Bankers Trainee (DBT)

- Mengevaluasi dan melakukan simflikasi proses rekruitmen terkait dengan proses wawancara dan matriks persetujuan paket remunerasi kandidat untuk diterapkan di tahun 2020

- Melakukan evaluasi atas penggunaan online tes psikometri yang digunakan agar dapat memenuhi kebutuhan kandidat DBT dan posisi yang bersifat masal khususnya di tahun 2020

- Menerapkan competency-based interview dalam proses wawancara serta memberikan pelatihan competencies based interview kepada user di direktorat branch network yang kerap melakukan wawancara karyawan baru khususnya sales marketing

- Bank Danamon melakukan review dan merubah Surat Penawaran Kerja (Offering Later) menjadi Surat Perjanjian Kerja (Employment Letter) untuk diterapkan pada tahun 2020.

Bank Danamon akan terus melakukan pengembangan proses rekruitmen berbasis digital secara bertahap sesuai dengan pengembangan dan kebutuhan organisasi serta agar dapat mengakomodir karakteristik khususnya kandidat milenials yang akan mendominasi pasar pencari kerja.

Tabel 7

Jumlah Karyawan Bank Danamon 2019

\begin{tabular}{|lccccc|}
\hline Tingkat Jabatan & $\mathbf{2 0 1 9}$ & $\mathbf{2 0 1 8}$ & $\mathbf{2 0 1 7}$ & $\mathbf{2 0 1 6}$ & $\mathbf{2 0 1 5}$ \\
$\begin{array}{l}\text { Manajemen } \\
\text { Puncak }\end{array}$ & 12 & 3 & 3 & 3 & 4 \\
\hline
\end{tabular}


ARTIKEL

\begin{tabular}{|lccccc|}
\hline Manajer Senior & 35 & 184 & 38 & 37 & 20 \\
Manajer & 182 & 1.213 & 247 & 136 & 95 \\
Officer & 1.088 & 194 & 1.385 & 1.173 & 800 \\
Staf & 2.952 & 4.503 & 5.705 & 9.159 & 10.808 \\
Jumlah & $\mathbf{4 . 2 6 9}$ & $\mathbf{6 . 0 9 7}$ & $\mathbf{7 . 3 7 8}$ & $\mathbf{1 0 . 5 0 8}$ & $\mathbf{1 1 . 7 2 7}$ \\
\hline
\end{tabular}

Sumber : Annual Report Bank Danamon 2019

Tabel 8

Jumlah Karyawan Bank Danamon

\begin{tabular}{|lccccc|}
\hline Fungsi Pekerjaan & $\mathbf{2 0 1 9}$ & $\mathbf{2 0 1 8}$ & $\mathbf{2 0 1 7}$ & $\mathbf{2 0 1 6}$ & $\mathbf{2 0 1 5}$ \\
Penjualan & 1.494 & 1.716 & 3.389 & 4.892 & 6.545 \\
Non-Penjualan & 2.775 & 4.381 & 3.989 & 5.616 & 5.182 \\
Jumlah & $\mathbf{4 . 2 6 9}$ & $\mathbf{6 . 0 9 7}$ & $\mathbf{7 . 3 7 8}$ & $\mathbf{1 0 . 5 0 8}$ & $\mathbf{1 1 . 7 2 7}$ \\
\hline
\end{tabular}

Sumber : Annual Report Bank Danamon 2019

\section{Pembahasan}

Berdasarkan hasil analisis di atas Bank Danamon mengalami penurunan jumlah karyawan setiap tahunnya. Hal tersebut disebabkan karena adanya merger antara Bank Danamon dengan BNP. Bank Danamon memiliki program DBT (Danamon Bankers Trainee) yaitu program Management Trainee Bank Danamon dimana para lulusan baru berbakat diberikan kesempatan untuk mencari pengalaman di berbagai bisnis, divisi dan fungsi di dalam Bank. Dengan persaingan yang ketat serta potensi bakat yang dimiliki oleh calon karyawan Bank Danamon maka akan mempengaruhi kualitas kinerja dari karyawan Bank Danamon itu sendiri.

Program pengembangan Talent Management dan karir karyawan merupakan bagian yang menjadi perhatian Direktorat Human Capital Bank Danamon. Program pengelolaan pelatihan dan pengembangan karyawan disusun secara komprehensif dan berkesinambungan, dengan tujuan memastikan ketersediaan dan kesiapan penerus kepemimpinan serta posisi penting lainnya di dalam perusahaan. Dengan adanya program tersebut bertujuan untuk memupuk pemimpin Bank Danamon dengan memperkuat pengetahuan perbankan komprehensif mereka dan secara sistematis melakukan rotasi kerja untuk mempercepat kemajuan keterampilan karyawan. Bank 
Danamon harus terus melakukan pembaharuan dalam menjalankan program pelatihan dan pengembangan serta proses rekruitmen yang ketat, untuk menciptakan kualitas kinerja yang lebih baik di lingkungan Bank Danamon.

\section{E. KESIMPULAN}

PT Bank Danamon Indonesia Tbk yang berdiri sejak 1956, per 31 Desember 2019 mengelola aset sebesar Rp194 triliun bersama anak perusahaannya, yaitu PT Adira Dinamika Multi Finance Tbk. (Adira Finance). Dalam hal kepemilikan saham, 94,1\% saham Bank Danamon dimiliki oleh MUFG Bank, Ltd. dan 5,9\% dimiliki oleh publik. Dengan kehadiran MUFG, karyawan Bank Danamon memiliki akses ke Digital Innovation Center milik MUFG Bank yang berada di Silicon Valley, California, New York, London, dan Singapura yang dapat memperkuat kemampuan digital karyawan yang tentunya akan membantu dalam melayani kebutuhan nasabah.

Bank Danamon memiliki banyak program dalam meningkatkan kualitas kinerja karyawan, salah satunya program DBT (Danamon Bankers Trainee). Danamon Bankers Trainee merupakan sejenis Management Trainee ataupun Officer Development Program yang baru ada sejak tahun 2017. Program ini meliputi pendidikan dan on the job training selama dua tahun dan memiliki sistem cut untuk setiap periodenya jika peserta didik dinilai tidak memenuhi kualifikasi standar dari perusahaan. Selain itu, Danamon telah mengembangkan pelatihan dan bimbingan onthe-job training yang pelaksanaannya dibantu oleh karyawan yang lebih berpengalaman atau supervisor sebagai mentor terhadap bawahan mereka. Topik pelatihan dan pelajaran yang mencakup kemampuan manajerial, keterampilan teknis, kursus penyegaran, kursus hak asasi manusia, dan lain sebagainya.

\section{DAFTAR PUSTAKA}

Hasibuan, Malayu. (2009). Manajemen Sumber Daya Manusia. Jakarta : Bumi Aksara

Randall, Schuler dan Susan E Jackson.(1997). Manajemen Sumber Daya Manusia Menghadapi Abad 21. Jakarta : Erlangga

Nawawi, A.Kadir.(1997). Manajemen Sumber Daya Manusia Untuk Bisnis yang Kompetitif. Yogyakarta : Gajah Mada University Press 
Pratama, Rio Aan, dkk. (2017). Pengaruh Rekruitmen, Penempatan Dan Pelatihan Terhadap Kinerja Karyawan Pada PT.Unilever Indonesia, Tbk. Surabaya : Universitas Bhayangkara. Diakses 14 Juli 2020.

Sunarsi, Denok. (2018). Pengaruh Rekruitmen, Seleksi Dan Pelatihan Terhadap Produktivitas Kinerja Karyawan. Prodi Manajemen Fakultas Ekonomi Universitas Pamulang. Diakses 14 Juli 2020.

Dharmawan, Rafi dkk. 2018. Analisis Efisiensi Rekrutmen Karyawan Melalui Media Online Dan Media Konvensional (Studi Tentang Efisiensi Waktu dan Tenaga dari PT. Jasa Marga (persero) Tbk). Malang : Universitas Brawijaya. Diakses 22 Juni 2020.

https://sesamamahasiswa.blogspot.com/2018/08/pengertian-kinerja-karyawan$\underline{\text { menurut.html }}$

http://eprints.polsri.ac.id/3004/3/BAB\%20II.pdf

https://www.danamon.co.id/id/Karir/TentangKarirLulusanBaru/Danamon-BankersTrainee

Annual Report Bank Danamon 2017

Annual Report Bank Danamon 2018

Annual Report Bank Danamon 2019 